\title{
Patriarchy, Privilege, and Power: Intimacies and Bargains in Ethnographic Production
}

\author{
HOLLEY DONAHUE SINGH \\ Population Studies Center \\ $U$ niversity of $M$ ichigan \\ 426 Thompson St \\ A nn A rbor, M I 48104
}

Summary: When an ethnographer's life is intimately enmeshed in the field through marriage or long-term partnership, what are the implications for ethnographic production? This article uses autoethnographic perspectives to engage issues of patriarchy, privilege, and power from fieldwork through the writing process. I argue that the power to represent these relationships must be examined to take anthropology beyond reflexivity to the realities of doing ethnography in an intimately interconnected world.

Keywords: fieldwork, ethnography, India, intimacy, privilege

Ethnographers need new ways of communicating shifts between participant and observer, family member and researcher, self and other, to take anthropology beyond reflexivity to the realities of doing ethnography in an intimately interconnected world. In this article, I draw on my experiences conducting ethnographic research as an, at-thetime, childfree United States-born daughter-in-law of a high-caste Hindu family working on the cultural dynamics of infertility among Hindu and Muslim women in Lucknow, India. I do not seek a reality show about the secret lives of anthropologists, nor a gratuitous quest to unearth the pain of anthropologists, but I maintain that intimate relationships are relevant to understanding the context and structure of research in cultural anthropology and how those relationships get represented in anthropological writing. I argue that the diffuse power to represent relationships This is the author manuscript accepted for publication and has undergone full peer review but has not been through the copyediting, typesetting, pagination and proofreading process, which may lead to differences between this version and the Version record. Please cite this article as doi:10.1111/ anhu.12104. 
among researchers, informants, family members, and friends oscillates depending upon their relationships to power, and that these relationships to power cannot be taken for granted, but need to be investigated throughout the process of ethnographic production.

\section{Intimacies and D ifference in South A sia: H istorical Perspectives}

"Whereof one cannot speak, thereof one must be silent." This quote from Wittgenstein serves as the epigram that frames The 0 chre Robe, the autobiography of Agehananda Bharati. Bharati, known to students and colleagues as "Swami ji" (personal communication, R.S. Khare) during his time as a professor of anthropology at Syracuse University, was born in Vienna, A ustria, as Leopold Fischer. Bharati joined a Hindu monastic order in India, received a new name and donned the robes that mark a religious renouncer. The act made him a dedared outsider to the daily lives of families, but a member of a fully Hindu institution, and he commenced to travel from village to village preaching. N ot all members of the order accepted his conversion, and although his facility for language meant that he was often taken to be an Indian, and despite having undergone all the requisite rituals, his legitimacy as a full member of the Dasanami order was often questioned. Bharati's commitment was life-long, and on the basis of that experience he advocated what he termed "cultural criticism," decades before A nthropology as Cultural Critique (Marcus and Fischer 1986). In Bharati's thinking, "cultural criticism" entailed using evidence to debate aspects of culture with which one disagrees. He concludes that 
I believe that cultural criticism is the only contribution we can make to cultures not originally our own, or not our own by choice.... The method tends to avoid the disastrous distinction between 'outsiders' and 'insiders,' for the fact that one contributes to a culture makes one an 'insider,' and if cultural criticism is successful then the critic becomes an 'insider' by virtue of the value of his criticism; or to be more exact, the distinction between 'outsider' and 'insider' becomes irrelevant. (Bharati 1970:276)

In South Asia, there is a long history of intimate relationships that defy a simple logic of defining selves and others. The example of Bharati the Hindu monk is an extreme one; there are many more examples to be drawn from the realm of householders. Although complex rules of endogamy have been dominant forces in the organization of marriage in South Asia, they have certainly not been practiced to the complete exclusion of other marital arrangements. The "white Mughals," for example, were European men who enmeshed themselves in Indian culture and married Indian women (Dal rymple 2004), even while acting as agents of the East India Company in eighteenth-century in India. However, restrictions were placed on inter-cultural intimacies from the mid-nineteenth century onward during the British Raj. These were particularly strict between European women and Indian men, as exemplified in fiction by, for example, E.M. Forster's (1924) A Passage to India.

In South A sian Studies and in anthropology since World War II, there are numerous examples of foreign scholars developing relationships that bring them into very close, long-term relationships with people of South Asian origin. When those relationships have involved friendship with, for example, a particular family, anthropologists have made those attachments a significant focus of research and a basis for examining cultural change in particular contexts. Margaret Trawick's ethnography 
on love in a Tamil family (Trawick 1990), Joyce Burkhalter Fleuckiger's work with a family of south Indian Muslim healers (Fleuckiger 2010, 2006), and Sylvia Vatuk's research with a south Indian Muslim family (Vatuk 1990, 1989) serve as outstanding models. Such relationships, as the ethnographers have described them, may indeed involve long-term obligations, but the ethnographer exerts significant control over the scope of the relationships. Representing research based on these close ties is not without its complexities, particularly when the ethnographer concerns him or herself with maintaining those relationships, knowing full well that his or her South Asian intimates may read the published work.

\section{Intimacies and Ethnographies}

When intimacies developed in the field involve scholars establishing socially recognized kinship ties- and herel do not mean short-term so-called "fictive" kinning as a daughter, son, sister, or brother, that lasts with greatest force as long as fieldwork does-but long-term ties not based on birth, such as marriage and adoption, anthropologists have been much more reticent. How have those relationships shaped their research agendas, the practicalities of their fieldwork, and the standpoint from which they analyze their data and write the worlds they have lived through fieldwork? How do the gender, class, and sexuality, for example, of foreign partners inflect social relations? Are these issues about which one must be silent?

I certainly do not advocate marriage or securing a bed-servant (Stoler 2002) as a method of dissolving an insider/ outsider tension. The ethical dimensions of such 
relationships are many and lie beyond the scope of this article. I hold that scholars should only venture to consider forming such intimacies when they understand the potential long-term implications for themselves and their intimates well. Even in the present, Indians who dare to cross boundaries of caste, class, religion, region, and/ or language in a "love" marriage often do so at the risk of their own social status-and sometimes, their lives (Chowdhry 2007). Yet, there are numerous examples of marriages between scholars from the U nited States and Indian citizens at least as far back as the mid-twentieth century. In that era, for example, anthropologists Harold Gould and Sylvia Vatuk both had spouses from India. One marriage lasted over the long term; the other did not. While the dynamics of these relationships may have been the topic of informal discussions, they have played little discernible role in the published scholarship of either. This is so even though Vatuk published with her first husband, the poet and folklorist Ved Prakash Vatuk, and has kept his name (actually his pen-name, which he adopted after renouncing his caste name) decades after the end of their marriage (Leonard, Reddy, and Gold 2010:8Here, I follow Khare (1992), who argued that

An anthropologist's self cannot any longer bracket itself off from the Other's dialogue, because the anthropologist lives in the company of the Other for years, not only to explain or interpret it in the context of his professional life (the "I" of published pages) but also to deal with it in his personal life....All issues of discourse parity, reciprocal knowledge sharing, and interdependent authenticity still remain unattended. To attend to them, we need a constant cultural criticism and historical reappraisal of the anthropologist's "I" (personal and professional) to redirect its one-sided selfprivileging tendencies. (Khare 1992: 7)

The most moving and memorable ethnographies that have shaped my own scholarship have been works that take very seriously calls from anthropology (Bateson 2012, 1989; 
Behar 1996; Khare 2011, 1992; Pinto 2014, 2011 [2008]) and feminist studies (Haraway 1988) for nuanced consideration of how researchers' personal histories shape the knowledge they generate at every stage of the research and writing process. Every researcher has particular positions in relation to the human beings from whom and with whom he or she learns—-whether it be with or against them (or both)—and whether they are called informants, participants, interlocutors, friends, enemies, or something else. Scholars who do interweave an evaluation of the researcher's "I" meaningfully into their ethnography, have been "moral pioneers" (Rapp 1998) themselves in acknowledging their intimate relations with the people and/ or topic they study. They have tackled the special advantages, challenges, pain, and frustration presented by those entwinements, and encouraged new generations of scholars to follow their model and answer Edith Turner's (2007) call for inclusion and validation of ethnographers' own experiences in their roles as co-producers of a humanistic anthropology (110).

For centuries, scholars of South A sian civilizations have come from a variety of indigenous and foreign backgrounds with particular institutional commitments that shape their perceptions and interpretations. Whether those obligations be to a local ruler, the leader of a colonial enterprise, a multinational charitable organization, a corporation, and/ or a university or other academic institution, they influence scholars' freedom of inquiry and speech in particular ways and limit the scope of their perception. In some ways, this idea of a point-of-view is common sense; yet, its implications for scholarship have too often been taken lightly, dismissed after a brief 
mention in the introduction. Feminist scholars, Dalit writers, and others who have seen themselves as occupying marginal positions and/ or the "savage slot" (Trouillot 1991) have taken their positioningand the issue of positioning very seriously as a fundamental aspect of knowledge production.. Anthropologists may be trained to notice different things than other people, but they are not trained out of their status as human beings living in the world with their own perspectives and own contributions. Richard Handler's (2004a) argument about difference in anthropology proves relevant to the ways I situated myself in writing the dissertation that grew out of my research in India. Handler argues that

[A ]nthropologists and "N atives," and outsiders and insiders, are never absolutely different, for difference is a matter of degree. Furthermore, the reality of difference, for all humans, is to be found in semiotic processes like translation and interpretation.... anthropological outsiders and the insiders they study (and who study them) must struggle to transcend their own familiar rationalizations in their attempts to understand one another. (H andler 2004a:488)

If there are no absolute differences between outsiders and insiders, if the problem is one of degrees of difference, then there is room for anthropologists to have many different positions vis-à-vis the communities with which they work. Then, too, their social locations are crucial to understanding the interpretations and representations generated out of their interactions. People living in India, particularly the over 300 million Indians who live in cities, conduct their daily activities across degrees of difference in regards to diversity of caste, class, region, religion, class, and gender (Khare 1992:10), and recognize the fact of significant variation in life experiences that arise from these factors. It is not uncommon for people to interview one another about the particularities of, for example, dowry, marriage, food habits, and agricultural products among people of 
their caste and locality in a manner akin to anthropological interviews. This stems partly from colonial legacies of the anthropological state (Dirks 2001), but also from long histories of co-habitation and interdependence through specialized division of labor and prescriptions for obligations entailed by, for example, the (often exploitative) jajmani system (Fuller 1989; Caldwell 1991).

In my dissertation work on women's experiences of dealing with infertility in northern India, conducted between 2005 and 2007 in the city of Lucknow, I was surprised to find that many people, despite their awareness of the diversity of women's positions according to these many axes of diversity, argued for the unity of women's experiences of infertility, regardless of their religious identity in particular. I heard not once, but many times from women who had not personally experienced infertility that this was a problem in which factors such as class and educational background might matter, but in which religious identity, so often cited as a primary access of difference among people in Uttar Pradesh, could not possibly influence women's actions (Singh 2011:143-144). Ideas about shared stigma and sentiment took precedence in arguments for the unity of women's quests for children.

\section{Personal Experience in Anthropologies of Reproduction}

In the anthropology of reproduction, a wholegeneration of scholars-most of them women and many of them self-identified feminists-have produced ethnographies that weave personal experience in various autoethnographic modes into their accounts, to the great benefit of readers. In some cases, it has been those personal 
experiences that inspired the project. For example, Rayna Rapp's experience of ending a wanted pregnancy after receiving a diagnosis of Down Syndrome led her to study amniocentesis among women from many backgrounds in N ew York City (Rapp 1999), and Linda Layne's history of seven miscarriages inspired her project on pregnancy loss support groups in the United States (Layne 2003). Both reflect on how their own points of view at times aligned with those of the people represented in their writing, and at other times did not, on the basis of ideology, ethnicity, nationality, religion, class, ability, and other axes of difference. Sarah Pinto $(2008,2011)$ and Cecilia Van Hollen (2003), have allowed their own experiences with pregnancy and birth to enliven their explication of local worlds of reproduction in north and south India, respectively. All of these accounts lead to questions about how much of their personal histories ethnographers should consider appropriate, and beyond that, morally necessary to hel ping readers make sense of their work. Is there a line that must not be crossed, a point beyond which ethnographers enter the real m of "too much information," too much intrusion into their "personal" lives to be relevant to the study at hand? Or do the questions ethnographers ask in work on family, kinship, and reproduction necessitate that ethnographers subject themselves to equal or greater exposure than the people with whom they work?

In her account of amniocentesis in New York City - her home - Rapp opens with a chapter titled, "How Methodology Bleeds into Daily Life" (1999:1). Here, the bleeding references not only lack of boundaries, blurriness of self and other, and blending of roles throughout many years of research and writing, but also effects of the research 
and writing process on her fully embodied selves, something she refers to as the "benefits, as well as the burdens, of reflexivity" (1999:14). I certainly experienced both benefits and burdens due to my social location as the daughter-in-law of an uppercaste, middle-dass $\mathrm{H}$ indu family during my dissertation fieldwork. These dynamics continue to shift over time and have influenced my writing process. They necessitate continuing engagement and encourage reevaluation of what I think I have known.

Rapp's reflections include ideas about how research "at home" muddies boundaries not only of self and other, but also of what constitutes research. She says, "when conducting fieldwork at home, the "outer reaches" of the sample bleed into daily reality. This constitutes both a great advantage for enforced wisdom, and a confusion for sampling parameters" (Rapp 1999:16). Globalization, social media, and other forces of the contemporary world have blurred all kinds of boundaries anthropologists once took for granted, but they have also changed anthropologists themselves. The lives of anthropologists often confound the notion of "home," especially as diverse reflexive anthropologists identify themselves as "halfies" (Abu-Lughod 1991), children of immigrants, refugees, third-culture kids, (works like this are too many to mention, but notably Mahdavi 2009; Thiranagama 2011), and others whose histories go far beyond colonial configurations of birth abroad. In my case, a firmly established sense of home rooted in land, family, and an extremely small rural community came unmoored when I left home for college. My own experiences of periodic itinerancy in graduate school and early professional employment, along with north Indian concepts of the sasural (father-in-law's place or marital home) as a married woman's true home, have colluded 
to further complicate what I might mean by "at home" and "in the field." At this stage, in some senses, I am at home in the field - in Lucknow, a city I have been returning to time and again since 2000, first as a student, then as a daughter-in-law carrying a Person of Indian Origin card, and now as the mother of a child who qualifies as an Overseas Citizen of India. Even in the United States, when asked for my permanent address, I think immediately of my parents-in-law's home address in Lucknow. They see this as entirely appropriate.

\section{Ethnographic Production: Fieldwork}

\section{Balancing Patriarchy}

In my doctoral dissertation (Singh 2011), I addressed my kinship networks in Lucknow at length, in an effort to make explicit my position as a researcher with significant personal attachments that would have implications for my ethnographic work in terms of the places and people with whom I could interact. I highlighted mainly religion and caste as locators with local resonance, and about which people asked me frequently during fieldwork. I followed the anthropological logic that resonated with me at that time, exemplified by Robert Desjarlais (1992):

Ethnography is divinatory by nature. Pierre Bourdieu and Renato Rosaldo contend that the anthropologist is a "positioned subject" in the social structure, holding a point of view that both fosters and inhibits particular kinds of insight. But I want to stress that the ethnographer's vision is both structured and hindered by local systems of knowledge. The field researcher connects with the same communicative pathways that her informants use; her blindspots and insights form part of the cultural cybernetic, her subjective position influences the interpretation of local sensibilities, and she is affected by similar cultural paradoxes and pathologies of knowledge. (Desjarlais 1992:24) 
I have had to contend with both parts of what Desjarlais identifies here: first, the idea of point of view —and not only vision, but fully embodied sensory experience- that influences the knowledges researchers are able to gather and absorb in the field.

Second, and this is more or less apparent to me at different moments, local values and systems of knowledgein Lucknow have seeped into my own body logic. Van Hollen has expressed a similar sentiment poignantly in describing her own reproductive loss, saying, "the cultural meanings of piracavam, vali, and sakti in Tamil N adu had seeped into me, informing my response to my own loss and transforming my own understanding of my body and my aspirations" (Van Hollen 2003:220). Something akin to this mingling of worldviews has influenced my own presentation of self in ways that ebb and flow depending on context, often without my conscious attempts to do so. In my fieldwork and dissertation, this produced an editing of my own background in the United States that often elided my experiences of growing up poor in rural western Pennsylvania.

Throughout the time of my doctoral field research, I was a married but childless - or rather, childfree —woman in my late twenties. In the context of my dissertation research, my social location in Lucknow was certainly significant. My husband, Deepak, belongs to a middle-class Kshatriya (upper-caste) family from Uttar Pradesh, and grew up in Lucknow, where we met and later married. By the time of my marriage, I had al ready spent over a year in north India, ind uding nine months residing in the women's hostel (dormitory complex) at Lucknow University. When I started my dissertation work, I had lived with my in-laws for a couple of summers while 
completing language study and preliminary research. My primary interest was to focus on Muslim women's perspectives on infertility and childlessness, and the places and peoplel visited in connection with my project reflect this. During my fieldwork, Deepak facilitated my daily comings-and-goings, often by driving me to meetings on his motor scooter. He sometimes introduced me to friends as potential research contacts, but he did not participate in interviews or act as translator for me. We talked often about the work throughout the process of research and writing, and both wondered whether we should represent this project as a collaborative effort, but ultimately did not, even though we had some models for doing so (Handler 2004b).

My in-laws were impressed with my efforts to learn Urdu, a language that both of my husband's grandfathers knew well, but which no one in the current generations can read or write. At the same time, my in-laws sometimes acted apologetic to their friends and relatives about my interests in Urdu language and were somewhat disturbed by my intentions to meet Muslim people across the social spectrum in Lucknow. These were partly anxieties associated with difference in class and religion, partly concern with the movement of a female member of the household without anyone to accompany her as chaperone or guardian. I was fortunate in that, without extreme protest on my part, they granted mea level of freedom of movement and freedom from regular household chores of which most middle-dass, Kshatriya daughters-in-law (bahus) would be jeal ous, al though they insisted that I carry a cell phone everywherel went. 
Kandyoti's (1988) analysis of the "patriarchal bargains" struck by women living in what she calls "classic patriarchy" (274) with north India as a prime example, reflects to some degree the experiences I had in my own home and the kinds of stories I heard from women about infertility and extended families, al beit inflected with nuances unique to their own class, caste, and religious positions. In my own case, I would prefer to describe my endeavors as being about balancing or moderating patriarchy, rather than "bargaining" with it, because I had a rather large range of options. As an educated, working woman with a foreign passport, I could leave the country, and everyone, including me, understood my residence to be temporary, even if repeated often and presumed to be part of the long-term trajectory of the family. I could make independent decisions about how to spend my money and be in contact with many people using internet and phone service, as well as connections with fairly powerful people rooted in my academic credentials. All of these factors increased my influence within the household, al though I acquiesced to many conventions of respect, conversation, and labor.

At the household level families expect to negotiate some complexities of interpersponal relations among selves and others. Dealing with difference is nothingnew in north India, but globalization, air transport, and migration for employment, as well as shifting gender norms, can increase the degrees of difference and potential conflict to be negotiated. The vast majority of marriages are still arranged by the families of prospective brides and grooms, and marriage rules and practices strongly tend to bring in daughters-in-laws (bahus) who will be seen by family members 
in this patrilocal system as Other. Even if they are of the same caste background as the family they enter, they likely hail from a different region, and there may be significant differences in financial and educational background between relatives from a new bride's maike, her natal home, and her sasural, her in-laws' home. Over time, with the birth of children, especially sons, and demonstrations of commitment to her in-laws' family, the otherness of daughters-in-law can potentially diminish, but their status as members of their maike never completely disappears. For me, entering my husband's household as a daughter-in-law, I was an Other of a different order than most, but I was not completely a stranger. My in-laws tolerated my otherness and touted my accomplishments in adjusting to their lifestyle in ways that few people would expect had their bahu come from a more familiar background.

My entwinements in Lucknow meant that I was immersed in a local community, including relatives, friends, and colleagues of my husband's family. I lived in a multigenerational joint family transitioning from one home to another in Lucknow itself, which meant that the family was sometimes dispersed in two different locations, but al ways together to make important decisions. Although I had a good measure of freedom, there were also certain gendered expectations that I abided by in order to protect the family's honor (izzat). I was also expected to fulfill, to at least to some extent, the roles of a daughter-in-law (bahu ), sister-in-law (bhäbhi, elder brother's wife), aunt (māmi, mother's brother's wife), and so on. Surveillance of my own fertility status became part of household conversations, in the form of questions such as, "when are you going to make your mother-in-law a grandmother (dādi)?" Luckily for me, 
throughout most of my graduate study, my mother-in-law took it upon herself to dismiss questions about children by explaining that I was still in school. These expectations would have been quite different, but not absent, had I been a foreign sonin-law, or damād.

At times, my research could benefit by my being party to some frank conversations about fertility and everyday life, induding household disputes and intimate details about fertility management. At other times, I could be ready to head off for a meeting somewhere when relatives, associates, or old friends of the family would turn up and need to be received with chai (tea) and conversation. When I lived in the women's hostel at Lucknow University, I had many such moments and thwarted exits from our shared living space, but, in the long run, some of my most valuable moments came from those pauses to enjoy the company and conversation of the young women with whom I lived. So, too, with participating in the life of the household; I have been fortunate that the times of frustration and pain have, so far, tended to be balanced with moments of contentment and joy. The richness of these experiences has also hel ped to moderate the intense lonel iness that anthropologists have often reported during extended periods of fieldwork.

Women I met in infertility clinics often presented themselves as being quite skillful in navigating familial dynamics in order to facilitate their attempts to overcome infertility, including recruiting help from other women in the household to complete the daily chores and procuring money to fund their endeavors. In many ways, these women, diverse in many ways, but united momentarily under the clinic gaze, were 
among the most successful among their peers in dealing with infertility. Making it to the government clinic with their husbands and with money in hand represented a significant achievement, emblematic of their value in the household, in some sense evading the structures of patriarchy in joint families while working to uphold it—or, at least, to appear to be doing so--through the active pursuit of procreation. Learning to recognize, work with, and work around gatekeepers in the family, in academic institutions, and in medical facilities, among others, hel ped all of us to strive toward our various goals, al beit with varying levels of success in working with and/ or evading these human politics that might otherwise threaten the viability of our endeavors (e.g., Motzafi-Haller 2009) or put us at risk of physical harm (Mahmood 2008; Times of India 2007).

Protean Selves

In reflection on my doctoral fieldwork days, I have sometimes found the pondering of interpersonal relations and the meanings of the body fascinating. At other times, I have found them infuriating, considering the issues of power and control over my body - a body caught up in a symbolic battle, the terms of which I have found myself unable or unwilling to assert—despite my feminist commitments, and knowing that I was far from al one in this struggle. At my most detached moments, it has seemed an elaborate demonstration of maya, the Hindu notion of the net of illusion in which human beings entangle themselves. 
The movement between different scripts of possible selves that might be multiple (Hardin and Clarke 2012: 30) is itself a kind of code-switching. In my case, my in-laws, interlocutors, and friends in the field played significant roles in shaping my presentation of selves (Goffman 1959) over the last decade or more, especially with reference to religion and class. In my life in India, this has meant not only movement among languages - English, Hindi, Urdu, Hinglish-in different situations, but also among registers of vocabulary in a variety of interactions. Would I speak of khuda or bhagvaan, both words for the divine, but the former more often used by Muslims, the latter by Hindus? A shabd or a lafz, words for "word" categorized as Hindi or Urdu? Baatchit or guftugu for conversation, dharmic or mazhabi for religious? Some of my codeswitching, or blurring of boundaries, created quandaries around dress, religion, and marital status that had not only implications for my status as an outsider or an insider, but also as a person placed locally in particular ways. My preference to wear shal waar kameez - tunics and loose pants topped off with a matching scarf-and rather modest forms of that dress (no sleevel ess tunics for me), marked me as less of an unknowing outsider, but did not el evate me to the status that daily sari wearing might have. It could al so have associated me with Indian ideas about "modern" women in an ambiguous way, positioning me as a respectable, but not overly cosmopolitan woman. My husband worried that if I wore saris on a regular basis, others would see me as a foreign freak, possibly a westerner attracted to a Hindu guru, swami, or other religious specialist-something he would not like others to presume about his wife because the presumed role also carried insinuations of drug use and sexual promiscuity. Suffice it 
to say, even within a familial context, the matter of my daily attire entailed multiple negotiations which have generally resulted in fashion sense bordering on the behenji, which means respected sister, but really shows that one is not very fashionable.

My experiences in India before and after marriage have made me aware of the placement of my body in physical and social space in new ways. They have drawn attention to the ways that others might read my body, my choice of fabric, print, color, length of tunic, sleeve, neckline, loose or tight trousers, to an extremel had never previously felt in the United States. The intricacies of womanly attire in north India slowly grew on me, from the dupatta (loose scarf), to bangles, to earrings, necklaces, anklets, and, after marriage, toe rings. For women, particular ornaments serve as more or less clear indications of marital status, religion, and class. Men's forms of dress do give indications of their status, but in much more vague terms, and the indicators for women apply most clearly to married women.

In my research work, I have moved among people of various religious, caste, and class backgrounds, primarily in Lucknow. I have found myself acutely aware of my presentation of self through my dress and adornments, not least because I have spent many hours listening to women critique one another's choices for particular occasions and relative to their body size and shape, their social status, and numerous other axes of identity. I have debated (mostly with myself), when and whether I should, must, or must not wear a bindi on my forehead in the manner of Hindu women. If so, how large? What color? If not, will I face criticism? Must I use sindoor, the red powder applied to the parting of one's hair by married Hindu women in north India? If so, how 
little can I apply and satisfy people who will be looking? How might these visible signs of Hindu identity affect my interactions with non-Hindu women? How would they influence the ways that activists for women's rights, academics, and others see me? In other words, I became obsessed with how a variety of others would read my in some ways advantaged, in other ways socially precarious, body, conscious of how others would position me (Robertson 2002:791) regardless of my own efforts to locate myself.

When I was preparing for dissertation fieldwork, the seeming advantages of such local connections, our engagements with postcolonial and postmodern scholarship, and our considerations of ethics and power relations in research led some of my colleagues to suggest (in jest) that I should tell people that I was infertile. Others said to me: "Wouldn't it be great for your research if you really were infertile?" Although family members in India deflected questions about our fertility status with aplomb by saying that I was still in school, people I met in connection with my research almost always interrogated me about my own status and sometimes chastened me for daring to put off childbearing in the pursuit of a doctoral degree. In particular, women being treated in infertility clinics sometimes asked me whether I myself was also getting treatment in the clinic, sincel did not have children and seemed to hang around there a lot. On many occasions, women chided me with admonitions such as, "hurry up and have children! You don't want to end up in here with us!" After months in the field, I began to find myself haunted by the specter of a future infertile self, perhaps brought on by the length of graduate work, by some joke of the universe, or by the wrath of an unnamed South 
Asian deity inadvertently offended by my work. Even then, I felt in no way prepared to undertake the business of fulfilling any patriarchal imperative to procreate.

\section{Protean Privilege}

After my marriage in India, I found that people expected me to wear jewelry, and especially gold ornaments. The expense of these adornments made me nervous because I feared losing them, having them stolen as I moved about the city, and causing financial hardship to myself or to those who purchased them for me. N ew outfits could requirenew bindis and new bangles, although I worked hard to keep neutral pieces that would minimize this requirement of my wardrobe. The imprint of my class origins followed me to India, even though I have generally been economically advantaged while living in India because of my connections to the United States.

$$
\text { Upper-caste Hindus and high-status Muslims-and especially Kshatriyas in }
$$

Uttar Pradesh, who have long historical connections with agricultural landholding as one foundation of their high status-have encouraged me to emphasize my (maternal) extended family's status as large landholders, rather than my own household's history of periodically living on food stamps, unemployment compensation, and income from my mother's factory job. Owning property in rural western Pennsylvania carries far fewer implications of wealth, prestige, power, and social status than would be the case in Uttar Pradesh, yet it fit in with local ideals of how to identify someone as "from a good family." My husband's family has discouraged me from talking too much with domestic workers about their lives and from sharing my own history of performing 
their own work (and more) in the United States, including summer work at a convenience store and a brief stint of employment as a professional cleaner before I started graduate school. A self-professed fat activist's statement about how fat can cling to one's identity, whether or not it currently clings to the body, resonates with my experiences of growing up in a home with few economic resources.

Once you are fat, you are marked in your psyche along with the stretch marks on your skin. You may have the privilege of passing as normal, depending on body size, but there will al ways be a part of "fat" that stays with you, that informs how you perceive the world and your place in it.... We are fat regardless of size. (Mitchell 2005:215)

Re-shaping narratives about my own life in the context of fieldwork has sometimes struck meas self-dissimulation-akin to the Shi'a Muslim notion of taqiyya, which allows a person to consciously downplay or hide certain aspects of one's identity (Virani 2011)_for building alliances across difference. At other times, it has smacked of patriarchal control against which I have felt the impulse to protest, but generally have not in the larger pragmatics of getting on with my work. In my worst moments, it has felt like the creation of an imposter, who would soon be discovered and summarily tossed out into the gutter.

Issues of privilege and privation must always be considered in relation to the situation at hand, while keeping global perspectives in mind. In the United States, I al ways valued the opportunities I received to study and travel in comparison to other members of my extended family. My progressive immersion in north Indian life has complicated those perceptions considerably, as is appropriate. Contemporary India, post-economic liberalization in 1991, displays similar patterns of inequality to the contemporary United States. However, those inequalities still jostle side-by-side in ways 
now uncommon in the United States. It is, I argue, inappropriate to see global inequal ities as the overriding consideration in power relations as they apply to ethnographic fieldwork and writing, and as al ways weighing in favor of the researcher. Depending upon their country of origin, researchers may indeed have significant advantages in terms of their freedom of movement, funding structure, prestige stemming from national origin and/ or institutional affiliation, race/ ethnicity, gender, sexuality, ability, and other dynamics. To assume that researchers are al ways advantaged in comparison to their interlocutors in the field in terms of economic privilege, however, misses an important potential axis of difference among scholars and, especially, the conditions of under which most doctoral students complete their degrees - that is, in relative economic privation within wealthy countries.

Many of the first gatekeepers that foreign researchers working in India encounter come from much more privileged backgrounds than the researchers themselves, al though it is quite possible that neither party will recognize this at once. Some markers of a history of privilege may include fluency in English, the assumption that others (servants, assistants, and/ or drivers) will be available to take care of daily tasks, combined with formidable self-possession and confidence, not to mention an abundance of consumer goods. Even within less economically privileged families, practices such as the joint residence of three or more generations in a common household and gendered division of labor within the household can create privilege that does not exist in many countries that send researchers to India - availability of child care, attention to children's schoolwork and activities, and freedom from 
household chores that have the potential to increase academic success. What I want to make clear here is the degree to which the unrecognized privilege of a lifetime in India can compensate to some extent for institutional barriers, such as lack of access to expensive journals and large class sizes, that researchers working in Indian institutions often face.

In my doctoral research, these contrasts were most apparent during my interactions with academics and prominent social activists, in comparison to the time I spent with women who occupied less prominent positions. All of these interactions required me to negotiate cultural differences as well as dass differences, and for me, the class differences proved to bethe more ethically intractable, and the ones that preyed most on my own "imposter syndrome" (Brookfield 1995). Maintaining relationships has involved not only balancing patriarchy, but also accepting bargains with privilege and working to model the assertive and self-assured presence of many of my interlocutors in India.

\section{Shifting Fields, Privilege, and Power: Writing}

Moving from primarily field research tasks to primarily writing tasks in ethnographic production undoubtedly shifts the locus of power toward the writer, more or less so depending upon whether the writing involves collaborators or, possibly, periodic critique by people who have participated in or observed the research process. As the writing of my doctoral dissertation progressed, I found myself paralyzed by the fear of misrepresenting the women who had honored my project by taking part in my 
research and plagued by yearning for the family, companions, and colleagues I had left behind. It was only when I returned to Lucknow for a span of several months that I felt this burden lift, as I was able to revisit some of the people and sites that had figured in my research and get feedback from numerous people in Lucknow in the midst of writing. Again, this predicament echoes not only preoccupations with power differentials or with linguistic struggles, but al so a gap in privilege that contributed even more to my existential doubts about ethnographic production that have driven debates for decades (Hardin and Clarke 2012; Behar and Gordon 1995; Fox 1991; Clifford and Marcus 1986).

Instant communication through e-mail and social media, as well as the internationalization and diversification of scholars producing ethnography continue to challenge ideas about who writes ethnography, and, perhaps to a lesser extent, who engages with, or consumes, ethnography (Jackson 2012). Connections through digital means create opportunities for interaction to continue past an ethnographer's physical presence at her field site, depending upon the digital literacy; accessibility of modes of communication, and the money and linguistic skills necessary to use them; and inclination of informants, collaborators, and/ or friends to engage with these technologies. These connections create quandaries about ethnographers' moral obligations, as Khare (2008) and Jackson (2012) have argued, but they also enable and encourage expanded roles for people involved in the ethnographer's gathering of data to influence the shape it takes as it becomes formal text suitable for publishing. 
India has over 980 million wireless phone subscribers (Telecom Regulatory Authority of India 2015), and over 125 million Facebook users (Times of India 2015)in addition to people who subscribe to other social media sites. N onetheless, class, urban or rural residence, and gender fundamental ly contribute to the structure of user communities. Fieldworkers may still find that the vast majority of their contacts have cell phones, but no access to a computer, the internet, or the basic English language skillsstill required to successfully operate computers in India because of sluggish development of software in regional languages. Maintaining communication with one's most privileged associates in the field remains the easiest continuing engagement, while others can more readily fade into the background. Overcoming such circumstances requires significant effort on the part of researchers, and the burden rightly falls on them to do so to the extent feasible. Continued interaction creates significant opportunities not only for ethical relationships, but also for clarification, revision, and inspiration concerning the research project as it changes from notes, interview data, journal entries, recordings, photographs, and other materials into texts, and, perhaps, visual content. For researchers with intimate connections in the field, especially family ties of any sort, some degree of continued interaction is all but unavoidable, and, I would argue, for the better, despite the complications it might introduce in everyday life back at researchers' home institutions.

Negotiations with privilege, too, continue in the course of academic careers, especially as graduate students transition into academic positions of their own. Here, too, much depends upon what sort of employment new scholars are able to attain, 
which allow them more or less time, mental space, and resources to pursue writing and research. The most fortunate will experience gains in privilege over time, with job security, stable salaries, and increasing respect and authority that may influence their authorial voices. Discussions in the Chronicle of H igher Education, The N ew Y ork Times, and other publications have taken up not only issues of faculty labor conditions in the United States, but al so economic class origins of college students as major issues in contemporary higher education (Kahlenberg 2013). These discussions have yet to extend to full consideration of the class origins of faculty in colleges and universities, which have in recent decades paid more attention to diversity in terms of race and ethnicity. To some people it may appear that my husband "married up" by joining me, but I would argue that the opposite is the case. Global inequalities and my privilegesthe most relevant ones at this historical juncture —United States citizenship, whiteness, and more-complicate simple contrasts. My husband's family al ways had a stable, middle-class income, while minestruggled financially. On the other hand, my family had access to dependable public schools and other benefits that offered me a slightly cracked open window of opportunity through which I slipped at my first chance, to college, graduate school, and academic employment.. The privileges I have gained through study and through scholarly workhave deepened my awareness of my own origins, and also helped me to re-evaluate my earlier writing and fieldwork projects. I have been hel ped al ong in these emerging realizations by writers such as Joanna Kadi, who writes of her own and her friends' life journeys: 
Whatever silly initials my friends and I carry after our names, we're still working-class....We don't float around thinking we're entitled to everything; we don't grab whatever we want. We don't acquire privilege, entitlement, and arrogance after slogging it out in the academy. (Kadi 1996[2006]:48)

The need for bargains with privilege, like those with patriarchy, are, mercifully but also maddeningly, open to challenge and renegotiation over the course of careers and lives. In our postcolonial, globalized and globalizing world, intimacies that cross what have become conventional boundaries of race, religion, caste, and nation are becoming more and more common the world over. Whether the degrees of difference are small or large, they are palpable to the people living them, and will inevitably influence the questions these people as researchers pose, the methods they use, the analysis they produce, and the practicalities of getting it all done.

\section{Conclusion}

My positions as a foreign researcher with an interest in Indo-M uslim culture and Urdu language, and presumed to be of Christian origin, and a daughter-in-law in a high-caste Hindu family have presented some challenges to my research, but shifts in my own analysis of self have also hel ped me approach research and writing from new perspectives. Attentiveness to my positionality has helped to me think about the larger picture of reproduction and social and religious conflicts in contemporary India. Nevertheless, attention to positioning researchers should not overwhelm the perspectives offered by interlocutors in fieldwork, nor in the overall publications that result. 
As my experiences changed over the course of my marriage and the unfolding of life events, so have my ethnographic experiences changed since 2002. The challenges and limitations of being part of a local family also suited my research, since there was no colony of infertile people for me to join as a round-the-clock participant-observer. This dynamic, however, al so meant that I could compare and contrast my own experiences with those of the women I met in Lucknow who were negotiating their own family situations. I carried with me the cautions not to assume that my perspectives could easily translate into theirs-akin to the perspective sensitively portrayed by Desjarlais (1992:14-30) while explaining his work with shamans in N epal-and not to allow my own voice to impoverish the voices of my interlocutors (Robertson 2002:786, 789). My own history of intimacies in Lucknow inspired me to work even harder to gain the facility in Hindi/ Urdu that would be crucial to my ability to do my research without having a translator present, a dynamic that would have made discussions about infertility infinitely more difficult.

I am more attentive to some of the practicalities of doing research in north India because of my particular social location within a family context in which I am invested for the long-term. While I see promise in the kinds of understanding generated by this intimacy, it is certainly not without its difficulties. On the other hand, such intimacies are likely to generate quite distinct forms of knowledge, in comparison to urban living in guest houses, apartments, or in separate flats within a large family bungal ow. Such isolation from the intimacy of daily life in close quarters was more difficult to avoid in the days when most anthropologists conducted village studies. I appreciate the full 
spectrum of research techniques available to people conducting ethnographic research, but I especially encourage researchers starting out to let go of their notions about comfort and personal space to engage the messy richness of family life, while protecting their personal safety. For people working within their own communities or "at home," it may also make sense to shift their residence and scope of social interactions to appreciate the diversity of lifeways in their midst.

I cannot deny that what happens in India, politically, economically, socially, and more, matters to me. The prospects for my life, thelife of my family, and the life of my child are bound up with what happens in India, as much as they are bound up with what happens in the United States and, indeed, elsewhere in the world. During my first trip to India as a student abroad, I began to learn this lesson of interconnection and interdependence through study of Buddhist traditions, and it is one whose import only continues to deepen with time. I am still cautious about the prospect of minimizing the diversity of human experiences and the significance of inequalities by making unconditional claims of human unity, something many of my interlocutors in my fieldhome do much more readily in some circumstances, and speak against with equal vehemence in others. The recognition that we are all bound up together I cannot escape, even though I enjoy privileges that give me more chances to move geographically and socially when the need arises than most of my interlocutors-to study, more than endure, as Paul Farmer reminds his readers about the distribution of privilege (Farmer 2003:224). The long and continuing process of living and producing ethnography helps me to further this awareness and allow myself to acknowledge love 
(Turner 2010:223) and transformation (Hardin and Clarke 2012:4-5), with the hope of learning not to overwhelm the wholeness of my interlocutors' lives (Khare 1992:14).

My plea is both for acknowledgement of the modesty of the knowledge that emerges through fieldwork and ethnographic writing because of its deeply situated and specific nature, and also for recognition of the richness of this knowledge precisely because of the potential it has to permeate ethnographers' own lives. Cultivating and communicating these varieties of experience should help us understand better how social locations in fieldwork allow particular ways of existing in the world to seep into researchers' bodies and beings and bleed into their writing, while developing fuller appreciation for the diverse worlds that exist within these unstable spaces defined as "the field" and "home." Our degrees of difference, and how the nearness and distance shape our formulations of research questions, our strategies for carrying out research, and our ways of writing need continual examination to account for shifting relations of power throughout the long process involved in ethnographic production in our intimately interwoven world.

\section{Acknowledgements}

I gratefully acknowledge use of the services and facilities of the Population Studies

Center at the University of Michigan, funded by Eunice Kennedy Shriver $\mathrm{N}$ ational Institute of Child Health and Human Development (NICHD) Center Grant (R24 HD041028), support from an NICHD training grant to the PSC at the University of Michigan (T32 HD007339), and research grants from the A merican Institute of Indian 
Studies and the University of Virginia. I received encouragement from colleagues at Kenyon College and at the University of N otre Dame. Thank you to the organizers and fellow panelists for "Traces of the Ethnographer in the Ethnography: Reflexivity, Connectivity, and Relevance" at the 2011 A merican Anthropological Association meetings, where this work was first presented, to the editorial staff and reviewers at Anthropology and Humanism, and to the fellow life travelers have shared their time with mein India.

\section{References Cited}

Abu-Lughod, Lila

1991 "Writing A gainst Culture." In Recapturing A nthropology: W orking in the Present, R. G. Fox, editor, pp. 137-162. Santa Fe: School of A merican Research Press.

Bateson, Mary Catherine 2012 "Participant Observation as a Way of Living." In Rebecca Hardin and Kamari Maxine Clarke, editors. Transforming Ethnographic Knowledge. Madison: University of Wisconsin Press, pp. 37-50.

1989 Composing a Life. New York: Altantic Monthly Press.

Behar, Ruth

1996 The V ulnerable O bserver: A nthropol ogy That Breaks Y our H eart. Boston: Beacon Press.

Behar, Ruth and Deborah A. Gordon

1995 W omen W riting Culture. Berkeley: University of California Press.

Bharati, Agehananda

1970 The 0 chre Robe: A n A utobiography. N ew York: Doubleday and Co. Brookfield, S. D.

1995 Becoming a C ritically R eflective Teacher. San Francisco: Jossey Bass.

Caldwell, Bruce

1991 Jajmani System: An Investigation. Delhi: Hindustan Publishing Corporation.

Chowdhry, Prem

2007 Contentious M arriages, Eloping Couples: Gender, Caste, and Patriarchy in N orthern India. New Delhi: Oxford University Press.

Clifford, James, and George E. Marcus

1986 W riting Culture: The Poetics and Politics of Ethnography. Berkeley: University of California Press.

Dalrymple, William 
2004 W hite M ughals: Love and Betrayal in 18th-century India. N ew York: Penguin. Desjarlais, Robert R.

1992 B ody and E motion: The A esthetics of IIIness and H ealing in the $\mathrm{N}$ epal H imalayas. Philadel phia: University of Pennsylvania Press.

Dirks, Nicholas

2001 Castes of $M$ ind: Colonialism and the $M$ aking of $M$ odern India. Princeton: Princeton University Press.

Farmer, Paul

2003 Pathologies of P ower: H ealth, Human Rights, and the N ew War on the Poor.

Berkeley: University of California Press.

Flueckiger, Joyce Burkhalter

2010 "Courage and A uthority in the N ext Generation: Shifts in Gender Expectations and Performance in a Hyderabadi Sufi Healing Tradition." In $\mathrm{H}$ istories of Intimacy and Situated Ethnography, Karen Isaksen Leonard, Gayatri Reddy, and Ann Grodzins Gold, editors, pp. 233-252. New Delhi: Manohar.

2006 In A mma's H ealing Room: Gender and V ernacular Islam in South A sia. Bloomington: Indiana University Press.

Forster, E. M.

1924 A Passage to India. London: E. Arnold \& Co.

Fox, R. G., ed.

1991. Recapturing A nthropology: W orking in the Present. Santa Fe: School of A merican

Fuller, C.J. Research Press.

1989 “Misconceiving the Grain Heap: A Critique of the Concept of the Indian Jajmani System." In M oney and the M orality of Exchange, Parry, Jonathan P., and Maurice Bloch, editors, pp. 33-63. New York: Cambridge University Press.

Goffman, Erving 1959 The Presentation of Self in Everyday Life. New York: Doubleday.

Handler, Richard 2004a. "Afterword: Mysteries of Culture." American Anthropologist 106(3):488-494. 2004b. ed. Significant Others: Interpersonal and Professional Commitments in Anthropology. Madison: University of Wisconsin Press.

Haraway, Donna

1988 "Situated Knowledges: The Science Question in Feminism and the Privilege of Partial Perspective." Feminist Studies 14(3):575-600.

Hardin, Rebecca, and Kamari Maxine Clarke, editors 2012 Transforming Ethnographic Knowledge. Madison: University of Wisconsin Press. Jackson, John L., Jr. 2012 “Ethnography Is, Ethnography Ain't." Cultural A nthropology 27(3):480-497. Kadi, Joanna

1996 “Stupidity 'Deconstructed'." In Thinking Class, pp. 39-57. Boston: South End Press.

Kahlenberg, Richard D. 
2013 “How Much Do You Pay for College?” The Chronicle of Higher Education: The Chronicle Review. February 14.

Kandiyoti, Deniz

1988 "Bargaining with Patriarchy." Gender and Society 2(3):274-290.

Khare, R.S.

2011 "The U nch- $\mathrm{N}$ ich Challenge in Life: Changing Locations, Forces, and Meanings."

In Caste in Life: Experiencing In equalities, D. Shyam Babu and R.S. Khare, editors, pp. 20-32. New Delhi: Pearson.

2008 "Anthropology, India, and A cademic Self: A Disciplinary Journey Between

Two Cultures over Four Decades." India Review 7(4):349-377.

1992 "The Other's Double. The Anthropologist's Bracketed Self: N otes on Cultural

Representation and Privileged Discourse." N ew Literary H istory 23(1):1-23.

Layne, Linda L.

2003 M otherhood Lost: A Feminist A ccount of Pregnancy Loss In A merica. New York:

Routledge.

Leonard, Karen Isaksen, Gayatri Reddy, and Ann Grodzins Gold

2010 "Introduction." In H istories of Intimacy and Situated Ethnography, pp. 7-20. N ew

Delhi: Manohar.

Mahdavi, Pardis

2009 Passionate U prisings: Iran's Sexual Revolution. Stanford: Stanford University

Press.

Mahmood, Cynthia

2008 "A nthropology from the Bones: A Memoir of Fieldwork, Survival, and

I Commitment." A nthropology and H umanism 33(1/2):1-11.

Marcus, George E, and Michael M. J. Fischer

1986 A nthropology As Cultural Critique: an Experimental M oment In the H uman Sciences.

Mitchell, Allyson

Chicago: University of Chicago Press.

2005 "Pissed Off." In Fat: The A nthropology of an O bsession, Don Kulick and Anne

Meneley, editors., pp. 211-226. N ew York: Jeremy P. Tarcher/ Penguin.

Motzafi-Haller, Pnina

2009 "When Classic Ethnographic Work is Made Impossible: The Human Politics of

Research in India." A nthropology and H umanism 34(2):143-162.

Pinto, Sarah

2014 D aughters of Parvati: W omen and M adness in Contemporary India. Philadel phia:

University of Pennsylvania Press.

2011[2008] Where There is N o M idwife: Birth and Loss in Rural India. New York:

Berghahn Books.

Rapp, Rayna

1999 T esting W omen, Testing the F etus: The Social Impact of A mniocentesis in A merica.

New York: Routledge.

1988 “Moral Pioneers: Women, Men and Fetuses on a Frontier of Reproductive

Technology." In Embryos, Ethics, and Women's Rights: Exploring the $\mathrm{N}$ ew 
Reproductive Technologies, Baruch, Elaine H offman, A madeo F. D'A damo Jr., and Joni Seager, editors, pp. 101-116. N ew York: Haworth Press.

Singh, Holly Donahue

2011 "Aulad: Infertility and the Meanings of Children in N orth India." Ph.D. dissertation, Department of A nthropology, University of Virginia.

Stoler, Ann Laura

2002 Carnal Knowledge and Imperial Power: Race and the Intimate in Colonial Rule.

Berkeley: University of California Press.

Telecom Regulatory Authority of India

2015 "Highlights of Telecom Subscription Data as on 30th June, 2015." New Del hi:

Telecom Regulatory Authority of India.

http:/ / www.trai.gov.in/ WriteReadData/ WhatsN ew/ Documents/ PR-

N o=47.pdf, accessed 21 January 2016.

Times of India

2015 "Facebook's User Base Touches 125 Million in India." 29 June.

http:/ / timesofindia.indiatimes.com/ tech/ tech-news/ Facebooks-user-base-

touches-125-million-in- India/ artideshow/ 47866523.cms, accessed 21 January

2016. Times of India, Lucknow edition.

Thiranagama, Sharika

2011 In M y M other's H ouse: Civil War in Sri Lanka. Philadelphia: University of

Pennsylvania Press.

Trawick, Margaret

1990 N otes on Love in a Tamil Family. Berkeley: University of California Press.

Trouillot, Michel-Rolph

1991 "Anthropology and the Savage Slot: The Poetics and Politics of Otherness." In

Recapturing A nthropology: W orking in the Present, R. Fox, editor, pp. 17-44. Santa Fe: School of American Research Press.

Turner, Edith

2010 "Discussion: Ethnography as a Transformative Experience." Special Issue, "Do Spirits Exist? Ways to Know," A nthropology and H umanism 35(2):218-226.

2007 "Introduction to the Art of Ethnography." A nthropology and H umanism 32(2):108-116.

Van Hollen, Cecilia

2003 Birth on the Threshold: Childbirth and M odernity in South India. Berkeley:

Vatuk, Sylvia University of California Press.

1990 "The Cultural Construction of Shared Identity: A South Indian Muslim Family History." Special issue, "Person, Myth and Society in South Asian Islam," Social A nalysis 28:114-31.

1989 "H ousehold Form and Formation: Variability and Social Change among South Indian Muslims." In Society from the Inside 0 ut: A nthropological Perspectives on the South A sian H ousehold, J.N. Gray and D.J. Mearns, editors, pp. 107-139. N ew Delhi: Sage. 
Virani, Shafique N.

2011 "Taqiyya and Identity in a South A sian Community." The Journal of A sian Studies 70(1):99-139.
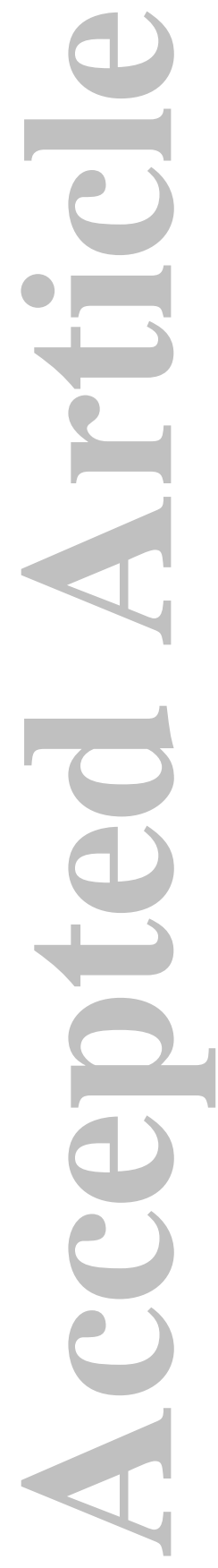

Singh, 36

This article is protected by copyright. All rights reserved. 